Article

\title{
Gene Expression and Photophysiological Changes in Pocillopora acuta Coral Holobiont Following Heat Stress and Recovery
}

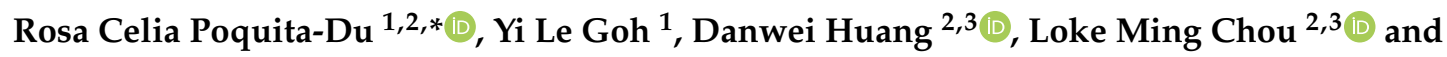 \\ Peter A. Todd ${ }^{1,2}$ \\ 1 Experimental Marine Ecology Laboratory, S3 Level 2, Department of Biological Sciences, National University \\ of Singapore, 16 Science Drive 4, Singapore 117558, Singapore; dbsgyl@nus.edu.sg (Y.L.G.); \\ dbspat@nus.edu.sg (P.A.T.) \\ 2 Tropical Marine Science Institute, National University of Singapore, S2S Building 18 Kent Ridge Road, \\ Singapore 119227, Singapore; huangdanwei@nus.edu.sg (D.H.); tmsclm@nus.edu.sg (L.M.C.) \\ 3 Reef Ecology Laboratory, S3 Level 4, Department of Biological Sciences, National University of Singapore, \\ 16 Science Drive 4, Singapore 117558, Singapore \\ * Correspondence: poquitadurc@nus.edu.sg; Tel.: +65-6601-2517
}

Received: 22 June 2020; Accepted: 9 August 2020; Published: 12 August 2020

\begin{abstract}
The ability of corals to withstand changes in their surroundings is a critical survival mechanism for coping with environmental stress. While many studies have examined responses of the coral holobiont to stressful conditions, its capacity to reverse responses and recover when the stressor is removed is not well-understood. In this study, we investigated among-colony responses of Pocillopora acuta from two sites with differing distance to the mainland (Kusu (closer to the mainland) and Raffles Lighthouse (further from the mainland)) to heat stress through differential expression analysis of target genes and quantification of photophysiological metrics. We then examined how these attributes were regulated after the stressor was removed to assess the recovery potential of P. acuta. The fragments that were subjected to heat stress $\left(2{ }^{\circ} \mathrm{C}\right.$ above ambient levels) generally exhibited significant reduction in their endosymbiont densities, but the extent of recovery following stress removal varied depending on natal site and colony. There were minimal changes in chl $a$ concentration and maximum quantum yield $(\mathrm{Fv} / \mathrm{Fm}$, the proportion of variable fluorescence $(\mathrm{Fv})$ to maximum fluorescence $(\mathrm{Fm}))$ in heat-stressed corals, suggesting that the algal endosymbionts' Photosystem II was not severely compromised. Significant changes in gene expression levels of selected genes of interest (GOI) were observed following heat exposure and stress removal among sites and colonies, including Actin, calcium/calmodulin-dependent protein kinase type IV (Camk4), kinesin-like protein (KIF9), and small heat shock protein 16.1 (Hsp16.1). The most responsive GOIs were Actin, a major component of the cytoskeleton, and the adaptive immune-related Camk4 which both showed significant reduction following heat exposure and subsequent upregulation during the recovery phase. Our findings clearly demonstrate specific responses of $P$. acuta in both photophysiological attributes and gene expression levels, suggesting differential capacity of $P$. acuta corals to tolerate heat stress depending on the colony, so that certain colonies may be more resilient than others.
\end{abstract}

Keywords: adaptive; immune response; heat; reversible phenotypic response; RT-qPCR

\section{Introduction}

Coral reefs are faced with severe degradation due to anthropogenic activities and the progression of climate change is exacerbating these stresses even further [1]. Perhaps the most apparent manifestation 
of global warming is an increase in sea surface temperature [2], affecting coral reefs worldwide [3,4]. This temperature rise can pose a threat not only to corals but also to a wide range of marine organisms [5]. Previous observations have shown impacts of elevated temperature on various biological processes crucial for coral survival such as calcification, immune and stress responses, as well as reproductive capacity [6,7]. When corals are exposed to heat beyond their tolerance limits, bleaching can occur such that corals dissociate from their photosynthetic endosymbionts which can be observed physically by the loss of pigmentation [8,9]. Severe bleaching of corals can lead to physiological damage, mass mortality, and changes in reef community composition [10-12].

The ability to constantly sense and exhibit flexibility to environmental changes is important for all organisms to maintain cellular homeostasis [13]. It is especially critical for corals as they are sessile and therefore more vulnerable to environmental variation than motile animals. Corals are known to exhibit a range of mechanisms to cope with changes in environmental conditions [14], including phenotypically plastic short-term reversible responses [15]. Phenotypic plasticity is defined as the capacity of an organism to alter a specific aspect of its phenotype, within its lifetime, in response to changes in its environment [16-18]. There are usually fitness costs and limitations associated with plasticity, and the degree of plastic responses exhibited depends on a balance between these factors and the overall benefits to the organism. Acclimatization is an example of plastic response that increases fitness in order to face environmental change [19].

Acclimatization mechanisms in corals generally include orchestration in levels of gene and protein expressions [20,21], heterotrophic activities [22], physiological attributes [23], and skeletal modifications [24,25]. More recently, studies on coral acclimatization mechanisms have focused on differential gene expression analysis as alteration in gene expression profiles is regarded as the underlying mechanism for phenotypic plasticity [26]. Gene expression links genotype to phenotype and plays a central role in cellular adaptation to environmental changes [27]. While gene expression analysis has emerged as a powerful tool in assessing acclimatization capacity of a coral species, one of the current challenges is the variability in gene expression levels among and even within coral colonies [28-31]. Different degrees of acclimatization capacity among coral colonies are generally expected [16,32] and are mostly influenced by genotype and natal environment, where the colony is from [33]. For example, in a reciprocal transplantation experiment of Porites astreoides from different populations - inshore versus offshore-a positive correlation between cellular stress response genes and measurement of fitness (i.e., growth, energetic stores, endosymbiont density, and chlorophyll content) was found for inshore coral fragments, suggesting enhanced plasticity is beneficial for this population of corals [34]. However, a negative correlation between the above-mentioned attributes was found for offshore coral fragments implying negative trade-offs ('costs') of the plastic response [34].

During a more recent coral bleaching events in Singapore, the coral genus Pocillopora appeared to show a shift to being less susceptible [12,35], similar to observationsfrom the Great Barrier Reef, Australia [36,37]. While this genus is known to be highly plastic [24,38,39], the mechanisms underlying its enhanced resistance to and ability to recover from thermal stress remain unclear. Therefore, it is of interest to explore both photophysiological and transcriptional plasticity in Pocillopora, using Pocillopora acuta as the model species. Here, we examine (1) how gene expression and photophysiological attributes (maximum quantum yield of Photosystem II (PII) (Fv/Fm, the proportion of variable fluorescence (Fv) to maximum fluorescence (Fm)), endosymbiont density, and chlorophyll (chl) $a$ concentration) among colonies of $P$. acuta corals are regulated in response to heat stress; (2) how these responses are then moderated after the stressor is removed, to assess their capacities to recover; and (3) whether responses vary depending on coral natal site and colony. 


\section{Materials and Methods}

\subsection{Experimental Design}

Six P. acuta colonies were collected from two sites-three colonies (labelled G1, G2, G3) were collected from a site near to Singapore's mainland (Kusu, $1.2257^{\circ} \mathrm{N} 103.8602^{\circ} \mathrm{E}$ ) and another three (G4, G5, G6) from further offshore (Raffles Lighthouse, $1.1602^{\circ} \mathrm{N} 103.7403^{\circ} \mathrm{E}$ ). The colonies were collected at least $\sim 10 \mathrm{~m}$ apart. Each colony was fragmented (total of 96 fragments $=$ six colonies $\times$ two treatments $\times$ two periods $\times$ four replicates) and placed in a flow-through aquarium facility for $5 \mathrm{~d}$ of acclimation.

A common garden experiment was conducted to examine photo-physiological performances and gene expression levels of $P$. acuta fragments from six colonies under two temperature treatments: heat stress $\left(32{ }^{\circ} \mathrm{C}\right)$ and ambient seawater temperature i.e., control $\left(30^{\circ} \mathrm{C}\right)$ at two periods (heat stress and recovery periods) (Figure 1 ). The "heat stress" period was created through repeated $4 \mathrm{~h}$ (10 a.m. to 2 p.m.) daily exposure of corals to heat $\left(32^{\circ} \mathrm{C}\right)$ for $5 \mathrm{~d}$, while for the "recovery" period, corals were allowed to recover for $36 \mathrm{~h}$ at $30^{\circ} \mathrm{C}$. The assigned temperatures for both control and treatment were based on previous data for sea surface temperature (SST) in Singapore where maximum monthly mean was $29.86^{\circ} \mathrm{C}$ and can rise $\geq 1{ }^{\circ} \mathrm{C}$ above this level during warmer periods (around April to July) $[12,35,40]$. The experiment was carried out in early July 2017, which falls within the warmer months, however, during this period, SST peaked at only $30.7^{\circ} \mathrm{C}$ in May and there were no reports of coral bleaching in local reefs [41].

Small rectangular plastic tanks (48 in total) were gravity-supplied with seawater from reservoirs and provided with constant aeration. All the small tanks were immersed in large fiberglass water baths maintained at two temperature levels: (1) $30{ }^{\circ} \mathrm{C}$ for the "control" and, (2) $32{ }^{\circ} \mathrm{C}$ for the "heat" treatment, using aquarium heaters (EHEIM Jagger). To ensure uniform temperature, a pump was used to circulate water throughout the bath. In each tank and water bath, temperature and light loggers (HOBO ${ }^{\circledR}$ U22-001 and UA-002-08, Onset Computer Corporation, Bourne, MA, USA) were set to log continuously every $5 \mathrm{~min}$ for the duration of the experiment. The tanks within the water bath were rearranged every 2 days to avoid any positional effects. Two coral fragments from the same colony were placed in each small tank. One fragment from each was collected after 5 days (the heat stress period) and used for destructive procedures, including sampling chl a concentration, endosymbiont density, and RNA extraction. The second fragment was collected after an additional $36 \mathrm{~h}$ for post-recovery sampling of the same photophysiological parameters mentioned above and gene expression levels. 

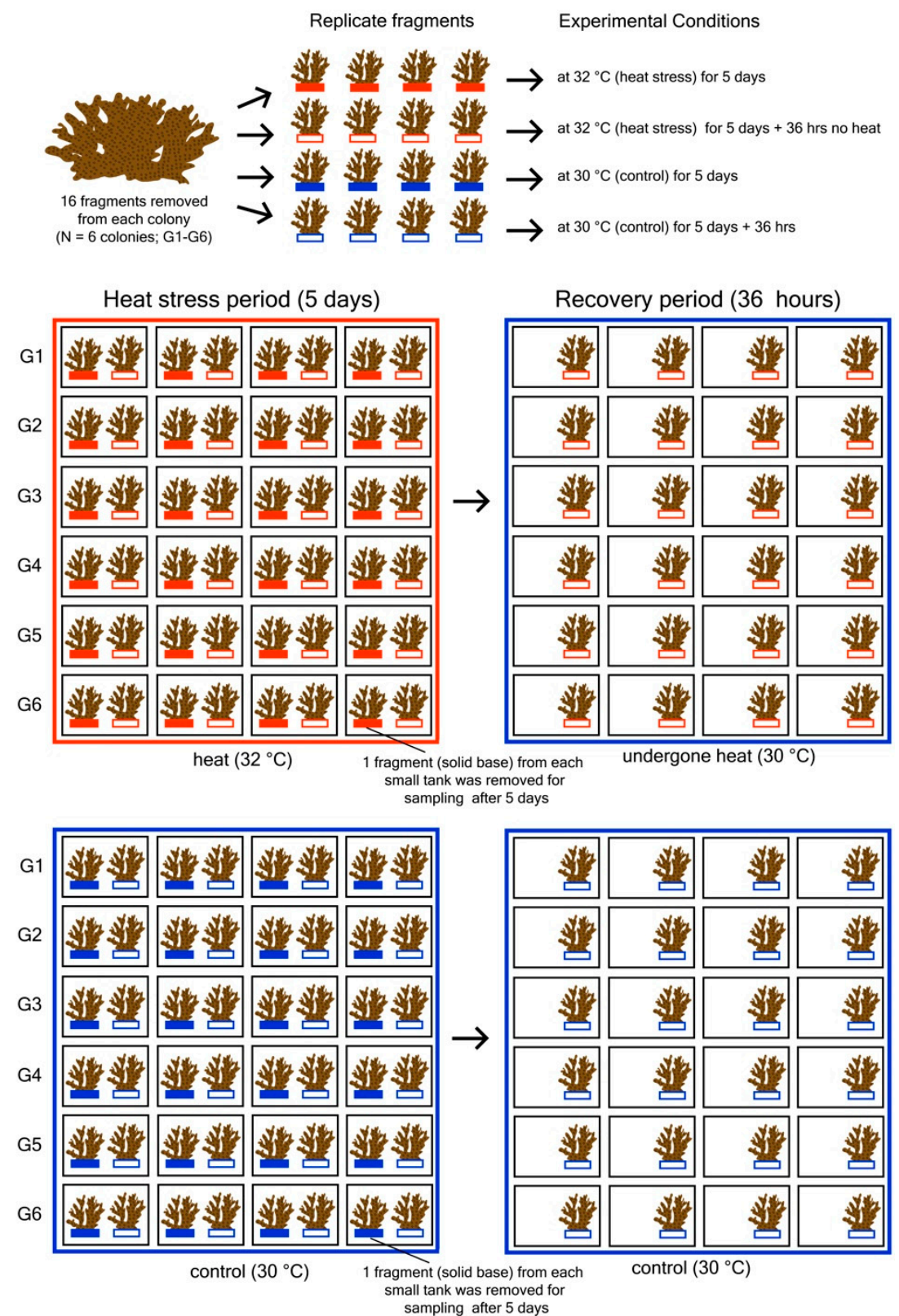

Figure 1. Experimental design showing each colony divided into fragments and assigned to two treatments (red fragment $=$ heat, blue fragments $=$ control) and periods (heat stress period, recovery period), totaling 96 fragments (two treatments $\times$ two periods $\times$ six colonies $\times$ four replicate fragments). A total of 24 small plastic tanks exposed to the heat treatment and 24 were controls; each contained two coral fragments from the same colony. Collection of 48 fragments (one from each small tank) was performed after 5 days for (destructive) analyses of endosymbiont density, chl $a$ concentration, and gene expression levels. The remaining 48 fragments remained in their tanks, allowing the previously-heat stressed fragments to recover for $36 \mathrm{~h}$ at ambient temperature $\left(30^{\circ} \mathrm{C}\right)$. All 48 fragments were collected after the recovery period for analysis.

2.2. Quantification of Maximum Quantum Yield (Fv/Fm), Endosymbiont Density, and Chlorophyll (chl) a Concentration

Measurements of $\mathrm{Fv} / \mathrm{Fm}$, chl $a$ concentration and endosymbiont density were taken from all coral fragments before the start of experiment, following "heat stress" (48 samples) and "recovery" (48 samples) periods. Measurements of Fv/Fm were conducted using a portable diving pulse amplitude modulating (PAM) fluorometer (Heinz Walz GmbH, Effeltrich, Germany) before sunrise, from 0300 to 
0700, to avoid any influences from changes in natural ambient light. Each fragment was sampled five times, aiming at different polyps on ends of upward-pointing branches and keeping a fixed distance of $5 \mathrm{~mm}$ between the fiber optic sensor and the coral surface [42]. All readings for each fragment sample were averaged.

Immediately after the heat stress period, 48 coral fragments (six colonies $\times$ two treatments $\times$ four replicates) were collected, wrapped in foil, and transferred to a cooler box for subsequent endosymbionts extraction following procedures from Ben-Haim et al. (2003) [43]. Another 48 coral samples were collected (from the coral fragments designated for the "recovery" period) $36 \mathrm{~h}$ after the heat stress was removed. To remove coral tissue from the skeleton, a Waterpik ${ }^{\circledR}$ water flosser was used and filled with filtered seawater. Mucus and clumping of endosymbiont cells were minimized by filtering the resultant slurry through 50 and $15 \mu \mathrm{m}$ plankton mesh nets. Cells were pelleted from the slurry by centrifugation (Eppendorf $5810 \mathrm{R}$ ) of $4000 \mathrm{rpm}$ for $30 \mathrm{~min}$ at $20^{\circ} \mathrm{C}$. Subsequently, the pellets were resuspended in $5 \mathrm{~mL}$ filtered seawater and stored at $-20^{\circ} \mathrm{C}$ until further analysis.

All samples containing endosymbiont suspension were vortexed to mix. Aliquots of $1 \mathrm{~mL}$ from the $5 \mathrm{~mL}$ suspension were set aside for cell counting and the remaining $4 \mathrm{~mL}$ saved for chl $a$ extraction. From the $1 \mathrm{~mL}$ aliquot, a subsample of $10 \mu \mathrm{L}$ was taken out for enumeration of endosymbiont cells using a Neubauer improved hemocytometer under a compound microscope, performed eight times. Prior to cell counting, aliquots were passed through a $27 \mathrm{G} \times \frac{1}{2}$ inch syringe to minimize clumping of endosymbiont cells. Subsequently, chl $a$ was extracted from the endosymbionts pelleted from the $4 \mathrm{~mL}$ aliquot using $100 \%$ acetone for $24 \mathrm{~h}$ at $4{ }^{\circ} \mathrm{C}$. Pigment absorbance readings were taken at 630,663 , and $750 \mathrm{~nm}$ using a UV-Vis spectrophotometer (UV-1280, Shimadzu, Japan) and chl a concentration was calculated using the equations from Jeffrey and Humphrey (1975) [44].

All fragments were photographed at a fixed vertical position with a ruler for image scaling. Using ImageJ (v. 1.50i), the boundary of a fragment from the background was delimited by tracing the shape of the fragment using both the polygon and wand tools and surface area was subsequently calculated using the integrated 'measure' function. As P. acuta is a branching coral, two opposite sides of the fragment were photographed to obtain a more representative surface area measurement. Finally, average values for endosymbiont cell density and chl $a$ concentration from each sample were normalized against coral surface area.

\subsection{RNA Extraction and Reverse Transcription (RT)}

In conjunction with coral sample collection for both periods described above, coral nubbins ( $\approx 2 \mathrm{~cm}$ branches) were removed from the replicate fragments for both treatments and placed in individual sample tubes pre-filled with RNAlater (ThermoFisher Scientific, Singapore) for stabilization. The sample tubes were inverted to mix for $30 \mathrm{~s}$ and kept at $4^{\circ} \mathrm{C}$ overnight to allow complete penetration of RNAlater into the coral tissues. The tubes were subsequently stored at $-80{ }^{\circ} \mathrm{C}$ until RNA extraction. Total RNA isolation was performed using TRIzol (Life Technologies, Sigma-Aldrich, Singapore), following manufacturer's protocol with slight modification to the homogenization procedure based on Barshis et al. (2013) [20]. RNA quality was checked by examining with gel electrophoresis for presence of clear bands of ribosomal RNAs, and RNA concentration was estimated using Qubit (RNA Broad Range Assay Kit, ThermoFisher Scientific, Singapore).

For each sample, complementary DNA (cDNA) was immediately prepared from the amount of total RNA equivalent to $1 \mu \mathrm{g}$, using a one-tube format of Bio-Rad iScript RT supermix for RT-qPCR (reverse transcription quantitative polymerase chain reaction). Reaction setup was composed of iScript RT supermix (4 $\mu \mathrm{L}$ ), RNA template (varied depending on RNA sample concentration; 14.6-200 ng/ $\mu \mathrm{L}$ ), and nuclease-free water (variable), with final volume of $20 \mu \mathrm{L}$. Incubation of reaction mix was performed in a Labcycler (Sensoquest, Göttingen, Germany) following the manufacturer's protocol: priming for 5 min at $25^{\circ} \mathrm{C}$, RT for $20 \mathrm{~min}$ at $46^{\circ} \mathrm{C}$, and RT inactivation for $1 \mathrm{~min}$ at $95^{\circ} \mathrm{C}$. 


\subsection{Primer Design and Validation}

The selected genes of interest (GOIs) and internal control genes (ICGs) were derived from an RNA-Seq experiment conducted on P. acuta following heat exposure [38] as being the most responsive and stable, respectively. The transcript sequences used for primer designs were validated to be associated with corals only as reported in Poquita-Du et al. [38]. The full list of candidate genes is shown in Table 1.

Table 1. List of genes of interest (GOIs) and internal control genes (ICGs) $\left(^{*}\right)$ with their corresponding functional profile (biological process) and primer designs.

\begin{tabular}{|c|c|c|}
\hline Gene Name (Abbreviation) & Biological Process & $\begin{array}{l}\text { Forward Primer } \\
\text { Reverse Primer }\end{array}$ \\
\hline Actin * & Cytoskeleton & $\begin{array}{c}\text { F: 5'-CAA GCA TCC TGT TCT CCT GAC-3' } \\
\text { R: 5'-AGG TAG GCC GTC AAG TCC C-3' }\end{array}$ \\
\hline $\begin{array}{l}\text { Acyl-CoA dehydrogenase family } \\
\text { member } 11(A C A D-11)^{*}\end{array}$ & Fatty acid beta-oxidation & $\begin{array}{c}\text { F: 5' } \text { 5AATCCAGCGACCCAGTGGA-3' }^{\prime} \\
\text { R: 5'-AAGCCAGGCCTTCTTTTGCT-3' }\end{array}$ \\
\hline Heat shock protein $70(H S P 70)^{*}$ & Stress response (heat) & $\begin{array}{l}\text { F: 5'-TTTCGACAACAAGGCCACGG-3' } \\
\text { R: 5'-TCTTCTTCGATCGTTAGGCGG-3' }\end{array}$ \\
\hline $\begin{array}{l}\text { Calcium/calmodulin-dependent } \\
\text { protein kinase type IV (Camk4) }\end{array}$ & Adaptive immune response & $\begin{array}{l}\text { F: 5'-GGA ACC CCT GGA TAC TGT GC-3' } \\
\text { R: 5'-ACA TCG CTT GAT CAC CTC GT-3' }\end{array}$ \\
\hline $\begin{array}{l}\text { EF-hand domain-containing } \\
\text { protein } 1(E F H 1)\end{array}$ & Cell cycle & $\begin{array}{l}\text { F: 5'-GTTCTACACCCCAGCTGACT-3' } \\
\text { R: } \text { 5'-CTTGTGGAACAGATGCCACC-3' }^{\prime}\end{array}$ \\
\hline $\begin{array}{l}\text { Growth arrest-specific protein } 8 \\
\text { (GAS8) }\end{array}$ & Cilia motility & $\begin{array}{l}\text { F: 5'-TGG AGA AGA AGG AAG CGC AG-3' } \\
\text { R: 5'-GTA CTC CGA ACG ACT GGA GC-3' }\end{array}$ \\
\hline $\begin{array}{l}\text { Small heat shock protein } 16.1 \\
\text { (Hsp16.1) }\end{array}$ & Stress response (heat) & $\begin{array}{l}\text { F: 5'-TGG TCA ACC CTT ACT GCC AT-3' } \\
\text { R: 5'-TCT CTC TCT GAG CGA TGC TG-3' }\end{array}$ \\
\hline Kinesin-like protein (KIF9) & $\begin{array}{l}\text { Extracellular matrix } \\
\text { disassembly }\end{array}$ & $\begin{array}{l}\text { F: 5'-CAA CGG AAC GAT TTT GGC GT-3' } \\
\text { R: 5'-GAT CCG TAC AGT CAC AGC GT-3' }\end{array}$ \\
\hline XIAP-associated factor 1 (XAF1) & Apoptosis & 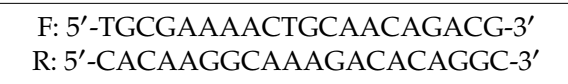 \\
\hline
\end{tabular}

Transcript sequences from Poquita-Du et al. [38] that matched selected GOIs were consolidated for alignment by gene for primer design. Primers for each gene were designed using the online tool by NCBI that incorporated Primer3 and BLAST (https://www.ncbi.nlm.nih.gov/tools/primer-blast/, June 2017), specifying "Pocillopora acuta" in the target organism field. Primer parameters include GC content $=50-60 \%$; $\operatorname{Tm}($ melting temperature $)=$ Min $58{ }^{\circ} \mathrm{C}$, Max $60{ }^{\circ} \mathrm{C}$, Tm difference $=1{ }^{\circ} \mathrm{C} ; \mathrm{PCR}$ product size $=$ Min 100, Max 1000. Forward primer sequences for each gene were searched in the consensus gene sequence used for the primer design. The reverse primer sequences were reversed using an online reverse primer tool (https://www.bioinformatics.org/sms/rev_comp.html, June 2017) and similarly searched against the consensus sequences.

The specificity of each primer pair for each GOI was verified by PCR using the GoTaq Green Master Mix. PCR reaction steps were (1) denaturation: $95^{\circ} \mathrm{C}$ for $45 \mathrm{~s}$ (2) annealing: start at $\sim 55^{\circ} \mathrm{C}$, increasing in increments of $1{ }^{\circ} \mathrm{C}$ to annealing temperature $\left(60^{\circ} \mathrm{C}\right)$ for $45 \mathrm{~s}$; (3) extension: $72-74{ }^{\circ} \mathrm{C}$ for $5 \mathrm{~min}$, repeated for 30 cycles. Gel electrophoresis was performed to check for successful amplification of target regions. Presence of gDNA contamination was also assessed using a no-RT control.

Efficiencies of primers were determined by amplifying a series of dilutions of $P$. acuta cDNA covering two orders of magnitude of template amount (0.078-5 ng) using qPCR (CFX96, Bio-Rad Laboratories, Hercules, California, USA). Calculations of efficiencies (E, the amplification factor per PCR cycle) needed to correct for amplification efficiencies per primer were done using MCMC.qpcr package in R developed by Matz et al. (2013) [45]. The function, PrimEff( ), calculates E and plots the regression slopes and E based on dilution series. The GOIs with E values outside the 1.85-2.15 range had primers redesigned and re-validated. GOIs which failed amplification were excluded from downstream analyses. 


\subsection{Quantification of Gene Expressions}

RT-qPCRs (15 $\mu$ L volume per reaction) were performed in Bio-Rad CFX96 using SsoAdvanced inhibitor-tolerant SYBR Green Supermix following the manufacturer's protocol (polymerase activation and DNA denaturation: 3 min at $98^{\circ} \mathrm{C}$, denaturation: $98^{\circ} \mathrm{C}$ for $15 \mathrm{~s}$, annealing/extension: $60^{\circ} \mathrm{C}$ for $45 \mathrm{~s}$, and plate read) repeated for 40 cycles. For each RT-qPCR run, three wells (technical replicates) were prepared for each cDNA sample in a 96-well hard-shell low-profile PCR plates with two wells each for no template and no-RT controls. Melting curve analysis $\left(65-95^{\circ} \mathrm{C}\right.$, increment of $0.5^{\circ} \mathrm{C}$ every $5 \mathrm{~s}$, and plate read) of the amplification product obtained was performed to further validate specificity of each primer. To control for variations in expressions of genes due to differences in RNA concentration of each sample, amount of cDNA template was standardized to $10 \mathrm{ng}$ of cDNA for every reaction mix.

\subsection{Statistical Analyses}

To examine the effects of "colony", "site", "treatment", and "period" on coral photophysiological performances, data were fitted with linear mixed models for Fv/Fm and chl $a$ concentration (continuous data) and generalized linear mixed model for endosymbiont density (count data) using lme4 package in R [46]. The fixed effect "colony" was nested within "site" to examine whether responses of corals within a site vary depending on the colony. The term "period" here does not refer to different time points of a treatment, but, rather, the effect of 'heat stress removal' for testing whether there were changes in the response of corals which had been subjected to heat, relative to the control samples (i.e., control fragments allotted mainly for the recovery period). The models for all photophysiological metrics contained "sample replicate" as a random effect. Stepwise model simplification and selection were based on Akaike information criterion. Visual inspections of the residual plots were performed to ensure assumptions of normality and homoscedasticity were met for all models.

Data obtained from RT-qPCRs expressed as "cycle of quantification values" (i.e., Cq values) were collated and sorted for subsequent analysis. The data contained raw $\mathrm{Cq}$ values from all biological ( $n=96$ samples from six colonies $\times$ two treatments $\times$ two periods $\times$ four replicates) and technical (three RT-qPCR reactions per sample) replicates for each GOI. Following the Bayesian methodology outlined by Matz et al. (2013) [45], the Cq values were converted into molecule counts with corrections for primer efficiencies using the MCMC.qpcr package in R. This approach relies on calculated amplification efficiencies (E) per gene and estimate of $\mathrm{Cq}$ for a single target molecule using a formula: Count $=\mathrm{E}(\mathrm{Cq} 1-\mathrm{Cq})$. The Cq-to-counts conversion is the key transformation in this method in which higher variation at the low gene expression values is properly accounted for by the relative quantification model. The transformation makes it possible to fit the resulting data to generalized linear mixed models to account for Poisson-distributed fluctuations when the number of molecule count is low. Similar Bayesian approaches for analyzing qPCR data have been used in several other reports [47-51]. While Actin was designated as an ICG, it was found to be differentially expressed following heat stress and, therefore, no longer utilized as an internal control here and the model was run in the "naive" form (i.e., no control gene). While specification of control genes can sharpen estimates of model parameters, this was not critical as all normalizations can be performed within the model [45].

Each gene profile was examined to determine (1) treatment responses, (2) whether changes of gene expressions for corals previously exposed to heat occurred following the recovery period, (3) among-site variation in responses, and (4) influence of colony. The model contained fixed effects: "treatment", "period", "site", and "colony"; a global fixed effect: "RNA quantity" (14.6-200 ng/ $\mu \mathrm{L}$ ) and a random effect: "sample replicate" that denotes individual cDNA preparations to account for unequal cDNA template loading between samples as a form of normalization. 


\section{Results}

\subsection{Photophysiological Performance}

Endosymbiont densities of $P$. acuta corals were significantly influenced by treatment (Chisq $=$ $\left.3.14 \times 10^{5} ; \mathrm{df}=1 ; p=2.2 \times 10^{-16}\right)$, period $\left(\right.$ Chisq $\left.=2.07 \times 10^{5} ; \mathrm{df}=1 ; p=2.2 \times 10^{-16}\right)$, site (Chisq $=7.33 ; \mathrm{df}=1 ; p=0.007$ ), and the interactions between these factors (Figure 2A; Table 2). However, the observed changes due to these factors significantly depended on the colony (Chisq $=2.58 \times 10^{6}$; $\left.\mathrm{df}=16 ; p=2.2 \times 10^{-16}\right)$.

A.

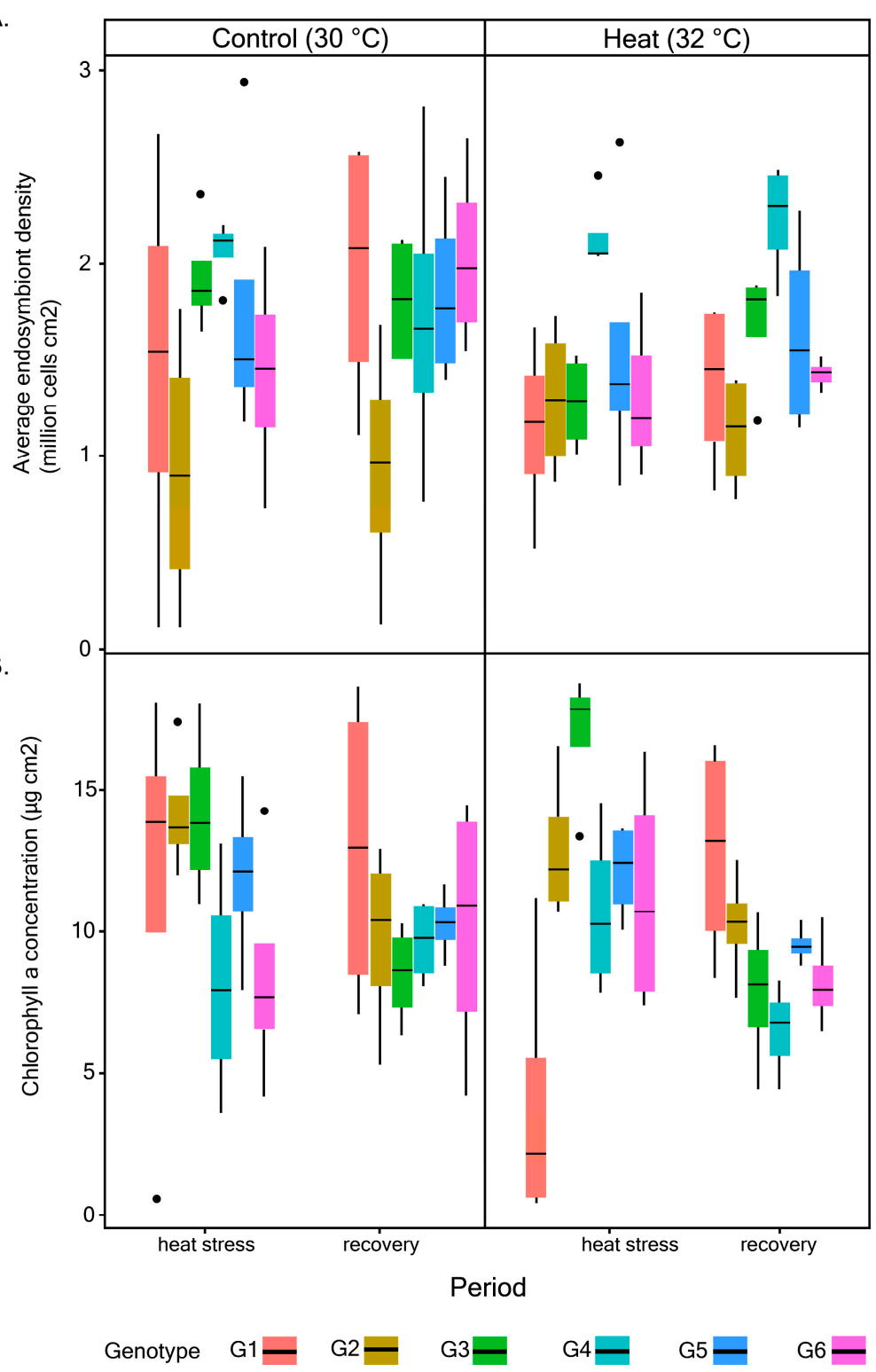

Figure 2. Changes in average endosymbiont density (A) and chl $a$ concentration (B) for all colonies across experimental conditions. 
Table 2. Results from generalized linear mixed model analysis for changes in endosymbiont density in response to individual factors (treatment, period, site, colony) and interaction between these factors. Significant values are in bold.

\begin{tabular}{|c|c|c|c|}
\hline \multicolumn{4}{|c|}{ Final model $=$ Average Endosymbiont Density $\sim$ Treatment $\times$ Period $\times$ Site $/$ Colony } \\
\hline Fixed effects & Chisq & Df & $p$ \\
\hline Treatment & $3.14 \times 10^{5}$ & 1 & $<2.2 \times 10^{-16}$ \\
\hline Period & $2.07 \times 10^{5}$ & 1 & $<2.2 \times 10^{-16}$ \\
\hline Site & $7.33 \times 10$ & 1 & 0.007 \\
\hline Treatment $\times$ period & $1.34 \times 10^{3}$ & 1 & $<2.2 \times 10^{-16}$ \\
\hline Treatment $\times$ site & $5.34 \times 10^{4}$ & 1 & $<2.2 \times 10^{-16}$ \\
\hline Period $\times$ site & $7.59 \times 10^{3}$ & 1 & $<2.2 \times 10^{-16}$ \\
\hline Treatment $\times$ period $\times$ site & $3.56 \times 10^{3}$ & 1 & $<2.2 \times 10^{-16}$ \\
\hline Treatment $\times$ period $\times$ site $\times$ colony & $2.58 \times 10^{6}$ & 16 & $<2.2 \times 10^{-16}$ \\
\hline
\end{tabular}

There were no significant changes for average chl $a$ concentration in response to heat across periods and sites. However, there were significant differences in response among colonies and sites (Chisq $=41.572 ; \mathrm{df}=16 ; p=0.0004$ ) (Figure 2B; Table 3). While the main effect of heat on the average $\mathrm{Fv} / \mathrm{Fm}$ of P. acuta corals was not significant, changes in $\mathrm{Fv} / \mathrm{Fm}$ differed significantly between experimental periods (Chisq $=5.7531 ; \mathrm{df}=1 ; p=0.016$ ) (Figure 3; Table 4). There were no significant differences between sites and among colonies.

Table 3. Results from linear mixed model analysis for changes in chl $a$ concentration in response to individual factors (treatment, period, site, colony) and interaction between these factors. Significant values are in bold.

\begin{tabular}{cccc}
\hline \multicolumn{5}{c}{ Final model $=$ Average chl $\boldsymbol{a}$ Concentration $\sim$ Treatment $\times$ Period $\times$ Site/Colony } \\
\hline Fixed effects & Chisq & Df & $p$ \\
\hline Treatment & 0.46 & 1 & 0.498 \\
\hline Period & 5.04 & 1 & $\mathbf{0 . 0 2 5}$ \\
\hline Site & 4.50 & 1 & $\mathbf{0 . 0 3 4}$ \\
\hline Treatment $\times$ period & 0.33 & 1 & 0.564 \\
\hline Treatment $\times$ site & 0.62 & 1 & 0.430 \\
\hline Period $\times$ site & 0.22 & 1 & 0.639 \\
\hline Treatment $\times$ period $\times$ site & 3.77 & 1 & 0.052 \\
\hline Treatment $\times$ period $\times$ site $\times$ colony & 41.57 & 16 & $<2.2 \times \mathbf{1 0} \mathbf{- 1 6}$ \\
\hline
\end{tabular}




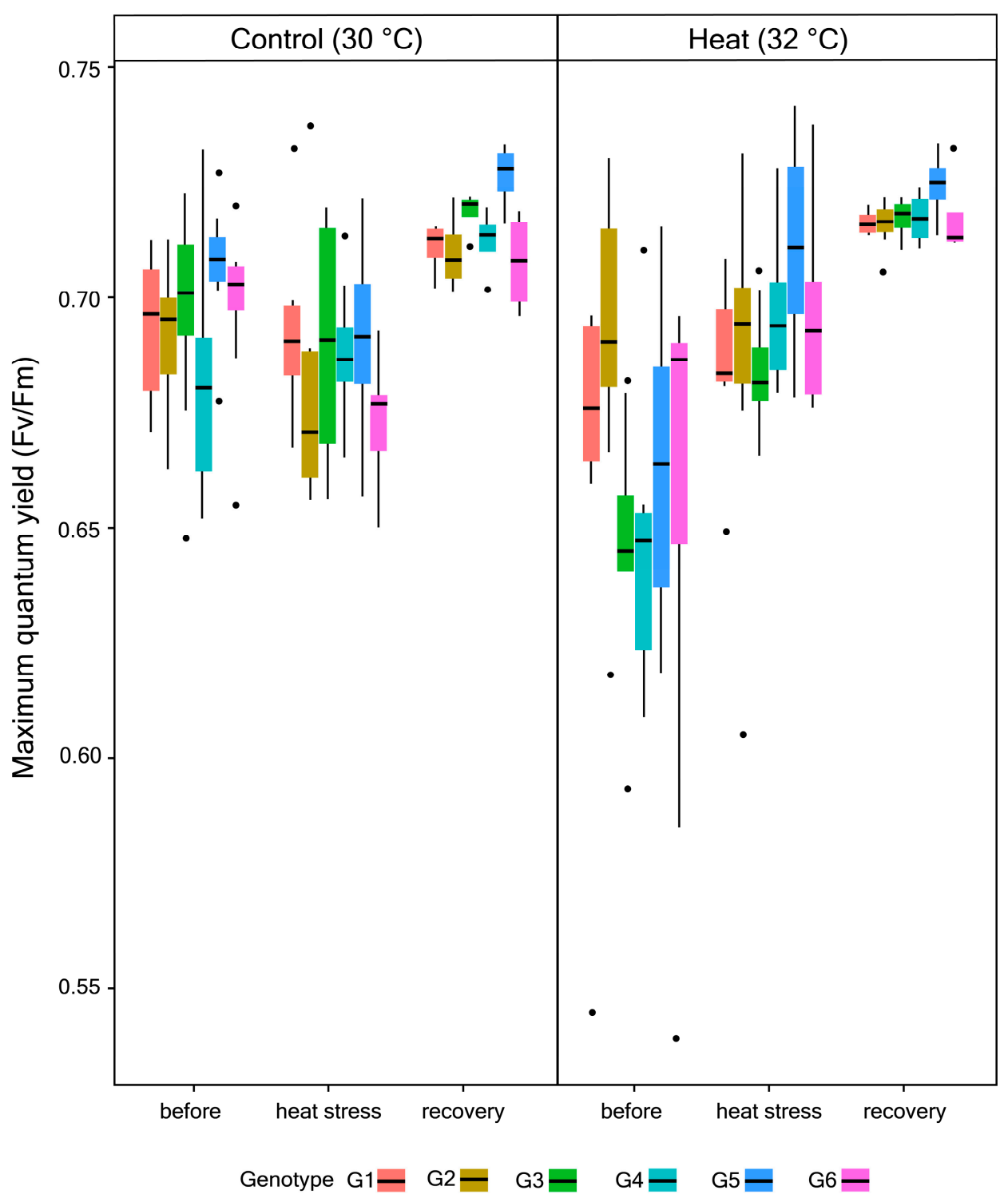

Figure 3. Changes in average Fv/Fm for all colonies across experimental conditions.

Table 4. Results from linear mixed model analysis for changes in Fv/Fm in response to individual factors (treatment, period, site, colony) and interaction between these factors. Significant values are in bold.

\begin{tabular}{cccc}
\hline \multicolumn{4}{c}{ Final $\mathbf{m o d e l}=$ Average $\mathbf{F}_{\mathbf{v}} / \mathbf{F}_{\mathbf{m}} \sim$ Treatment $\times$ Period $\times$ Site/Colony } \\
\hline Fixed effects & Chisq & Df & $p$ \\
\hline Treatment & 0.116 & 1 & 0.733 \\
\hline Period & 95.529 & 1 & $<\mathbf{2 . 2} \times \mathbf{1 0} \mathbf{- 1 6}$ \\
\hline Site & 1.531 & 1 & 0.216 \\
\hline Treatment $\times$ period & 5.753 & 1 & $\mathbf{0 . 0 1 6}$ \\
\hline Treatment $\times$ site & 0.183 & 1 & 0.669 \\
\hline Period $\times$ site & 0.184 & 1 & 0.668 \\
\hline Treatment $\times$ period $\times$ site & 0.659 & 1 & 0.417 \\
\hline Treatment $\times$ period $\times$ site $\times$ colony & 21.918 & 16 & 0.146 \\
\hline
\end{tabular}




\subsection{Primer Validation and Gene Expression Profiles}

Among the nine candidate genes, only five (Actin, Camk4, GAS8, Hsp16.1, and KIF9) showed reliable amplification. Efficiency of amplification was high, within the range of acceptable values of 1.49-2.1 (see Kenkel et al. (2011)) [28] (Figure S1).

The main effect of heat on expression levels of all genes examined was significant for only Actin (post. (posterior) mean $=-2.035 ;$ pMCMC $<0.001$ ) (Figure 4 and Data S1). Following the recovery period, heat-stressed corals particularly from G2 showed significant increase in expression levels of Actin (post. mean $=2.41$, pMCMC $=0.020$ ). While the overall changes in expression levels of Hsp16.1 and KIF9 following heat exposure were not significant, there were colony-specific differences, particularly for $\mathrm{G} 2$ (post. mean $=-2.10, \mathrm{pMCMC}=0.046$; post. mean $=11.67 \mathrm{~m}$ pMCMC $=0.038$, respectively). Further, corals which were previously exposed to heat showed upregulation of Camk4 during the recovery period, but this change was colony-specific with significant changes for G2 (post. mean $=4.28 ; \mathrm{pMCMC}=0.042$ ) and G3 (post. mean $=8.02 ;$ pMCMC < 0.001). Expression levels of GAS8 did not show any significant changes following heat stress and recovery among colonies and between sites.
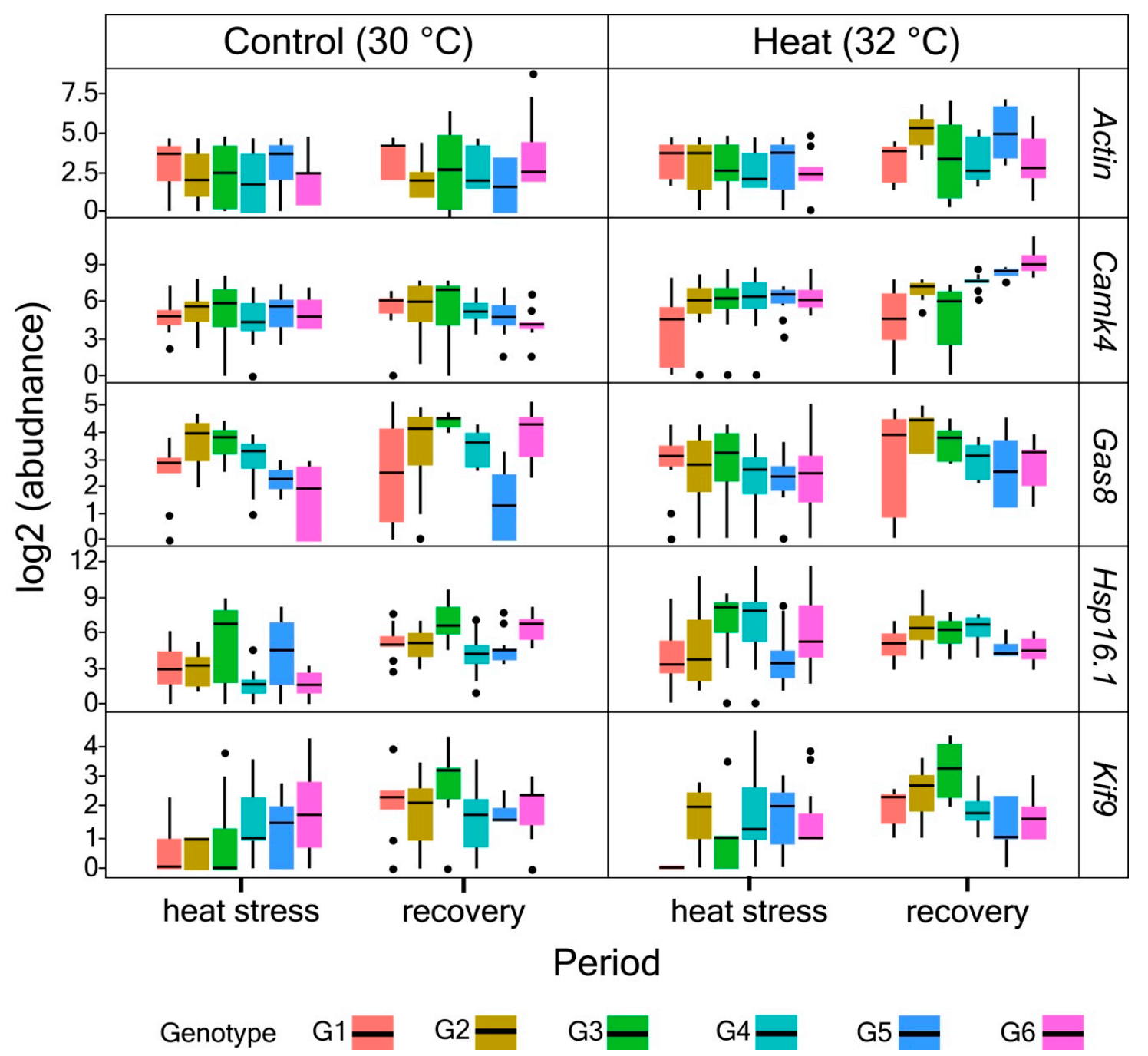

Figure 4. Changes in expression levels of all genes (log2-transformed) for all colonies examined across experimental conditions. 


\section{Discussion}

Our experiment tested how different colonies of $P$. acuta corals from two sites with differing distances to the mainland (Kusu (closer to the mainland) and Raffles Lighthouse (further from the mainland)) responded to heat stress and recover from it. Results showed that water temperature affected the photophysiological performances of $P$. acuta corals, after both the heat stress and recovery periods. Heat-induced differences in endosymbiont density between sites and among colonies were significant, as were changes in average chl $a$ concentration. Both treatment and experimental period influenced $\mathrm{F}_{\mathrm{v}} / \mathrm{F}_{\mathrm{m}}$ and responses were similar across sites and colonies. Significant changes in expression levels of selected GOIs were also detected, however, the changes were mainly colony-specific for most GOIs examined except for GAS8. The most responsive GOIs were Actin, a major component of the cytoskeleton and the adaptive immune-related gene Camk4. Both genes exhibited downregulation following exposure to heat and colony-specific changes in heat-stressed corals upon removal of the stressor. Findings here underscore the capacity of P. acuta corals to achieve homeostasis under sub-optimal conditions and recover from perturbations by a combination of photophysiological regulation and orchestration of gene expression.

Coral endosymbionts are known to adjust their photophysiological attributes to suit the surrounding conditions. Rising water temperature can cause dissociation of endosymbiotic dinoflagellates from their coral host and lead to loss of pigmentation, from either reduction in endosymbiont density or chl $a$ concentration [52,53]. However, the tendency of corals to undergo bleaching depends largely on the magnitude and duration of stress. Here, corals that were subjected to short-term heat stress $\left(2{ }^{\circ} \mathrm{C}\right.$ above normal levels) exhibited significant changes in their endosymbiont densities with specific responses dependent on colony and the natal site. Heat caused significant reductions in endosymbiont densities for all coral colonies, but the extent was less pronounced for corals from Raffles Lighthouse. However, one colony from this site (G4) showed significantly higher levels of endosymbiont density following heat exposure. A similar response has been observed previously for Pocillopora colonies exposed to heat stress (see $[38,54]$ ). Indeed, corals are known to regulate their endosymbiont abundance upwards under sub-optimal conditions to sustain high photosynthetic yield [55].

There were subsequent changes in endosymbiont densities for the heat-stressed corals after the stressor was removed but, again, there was variation in their recovery responses depending on colony and natal site. While there were significant changes in endosymbiont densities for most coral colonies, none of them showed visible changes in terms of tissue pigmentation (pers. obs). Furthermore, a small change in chl $a$ concentration in response to heat indicates the ability of endosymbionts to tolerate heat stress by just regulating their cell density without significant impact on chl $a$ concentration in the remaining viable endosymbiont cells. This response has been found previously for other coral species exposed to thermal stress, leading to $50-80 \%$ reduction in their endosymbiont cell densities without any influence on chl $a$ concentration [8]. Another study showed changes in endosymbiont density but no apparent effect on chl $a$ concentration in P. acuta coral exposed to heat [38], suggesting this is a typical response for P. acuta. The observed regulation in endosymbiont cell density and chl $a$ concentration here translated to minimal changes in $\mathrm{F}_{\mathrm{v}} / \mathrm{F}_{\mathrm{m}}$ following heat stress exposure, and a subsequent recovery when the stressor was removed. It has previously been suggested that acclimatization mechanism by endosymbiotic dinoflagellates under stressful conditions generally occur by modifying the reaction center (e.g., changing the abundance of the photosynthetic unit such as the Photosystem II) rather than the effective antennae-absorption involving chlorophyll $a$ [56]. However, the relationship is very complex due to packaging of pigments and how endosymbiont cells are packed within the coral cells [57]. These results demonstrate $P$. acuta's thermal tolerance and capacity to recover when conditions are improved. This can be attributed partly to the hosted endosymbionts which are known to be composed mainly of Durusdinium (previously Symbiodinium clade D) [58,59], a typically stress-tolerant Symbiodiniaceae. Findings here corroborate previous studies on Singapore's reefs that 
showed relatively high overall thermal tolerance, particularly corals from Raffles Lighthouse, and identified Pocillopora as one of the least susceptible genera [35,60].

While increased thermal tolerance is advantageous for coral survival, elevated temperature is often associated with growth impairment in corals as normal calcification physiology may be compromised [61-64]. Here, a significant downregulation of Actin was observed following heat exposure. Considering this is a major cytoskeletal component involved in growth, downregulation of this gene could be indicative of growth inhibition in response to heat stress. This pattern of Actin has previously been observed in similar experiments by Kenkel et al. (2011) [28] and DeSalvo et al. (2008) [65]. We note that Actin was initially tested as a control gene in this experiment based on its unresponsiveness to heat in our previous transcriptome-wide study of P. acuta [38]. However, the observed active regulation in Actin here indicates that its expression pattern may vary widely in this species. The gene's involvement in coral stress response needs to be further validated. Furthermore, KIF9, which is a kinesin-like protein linked to extracellular disassembly also showed changes in expression level following heat exposure. The extracellular calcifying matrix is the site of calcification [66,67], so changes in KIF9 are likely associated with regulation of the calcification process, which is controlled by exogenous factors such as temperature [68-71], among others. While these observations are consistent with current understanding of the effects of heat on coral growth and calcification rates, much work is needed to test this hypothesis in the future such as performing concurrent measurements of Actin and KIF9 expression levels and growth indices in corals following exposure to heat stress.

As most corals are sessile, the capacity to constantly sense their environment and respond specifically to a distinct stressor via adaptive immune responses is critical for their survival. Recent research on the genome of Pocillopora damicornis (a close relative to P. acuta) revealed the occurrence of lineage-specific genes that are associated with the immune response pathway, indicating that this species may have evolved unique immune strategies to cope with changes in the surrounding environment [72]. Here, exposure of corals to heat stress triggered downregulation of Camk4 expression levels which were then reversed significantly following removal of heat for some specific colonies (G2 and G3), particularly those from Kusu. The pattern of Camk4 during the recovery period appears to correspond to the site, suggesting a potential influence of natal site on coral responses to heat and its subsequent recovery. Kusu generally has a more variable environment compared to Raffles Lighthouse as it typically experiences strong tidal currents [73] and other external factors such as shipwakes [74] that may facilitate heat dissipation [75]. Camk4 is a calcium/calmodulin-dependent protein kinase which is associated to adaptive immune response [38] and has been reported to be an upstream regulator of the AMP-activated protein kinase (AMPK) system which is a critical regulator for energy balance observed in mammals [76]. The demand for energy during a stressful condition in corals is high [77], so the regulation of Camk4 which is activated by presence of $\mathrm{Ca}^{2+} /$ calmodulin ions [76], is potentially part of $P$. acuta's acclimatization response. It is interesting to note that the involvement of $\mathrm{Ca}^{2+}$ homeostasis disruption associated with thermal stress had been previously reported in cnidarians $[65,78,79]$ which further supports the role of Camk4 in coral stress response. While it is unclear whether or not corals have an adaptive immune response, the recent report on the genome of P. damicornis by Cunning et al. (2018) [72] highlighted some unique immune strategies in corals that have adaptive roles.

Heat-shock proteins $[6,80]$ in corals are also known to alleviate the negative impacts of heat stress by reducing the number of structurally non-native proteins produced by the endosymbionts. In Kenkel et al. (2011) [28], Hsp16.1 (a small Hsp) was upregulated following heat stress and subsequently downregulated for the recovery period. Conversely, in our study, exposure of $P$. acuta corals to heat showed slight increases of Hsp16.1, however, the change was only significant for G2. Interestingly, the expression levels of Hsp16.1 in heat-stressed corals appeared to increase following the recovery period and this was more pronounced for corals from Kusu compared to Raffles Lighthouse. These changes, however, were not significant. Nevertheless, the observations suggest a likely influence 
of natal site on the expression pattern of this gene similar to Camk4 discussed above. While the relationship between Hsp16.1 level and the water temperature profile of natal sites was not explored in this study, the pattern observed for this gene in response to heat stress corroborates previous observations $[20,28,38,81]$, highlighting its potential as a biomarker. However, considering the further increase of Hsp16.1 expression even when the stressor was removed, it is unclear what role this gene serves during a heat stress response.

The main findings here indicate strong intercolonial variability in $P . a c u t a$ 's response to heat stress and its capacity to recover. These differences are likely due to genotypic variability between the colonies examined and reflect the potential role this variation has for the resilience of this species in the face of climate change. It is worth mentioning that P. acuta corals found in Singapore exhibit variation in branching morphologies: compact and thin [82]. It has previously been shown that the two morphotypes displayed differential responses to thermal stress; the compact colonies were more heat-tolerant than those with thin branches [37]. This difference may be why the colonies examined here-which were of the compact morph-did not display bleaching throughout the experiment, despite the observed changes in photophysiological performances and gene expression levels. However, our findings indicate that even within the same morph, there is substantial variation in stress response. This highlights the importance of elucidating the underlying mechanisms explaining intercolonial variations in this species which may be due to genotypic variability, phenotypic plasticity as reported for other Pocillopora species [24,83-85], or a combination of both.

Taken together, findings presented here highlight significant regulation of photophysiological attributes and gene expression of P. acuta corals in response to changing thermal conditions which, however, depended largely on the coral colony. It is important to note that the underlying factors driving these differences remain unclear and warrant further investigation. In particular, as gene expression is followed by post-transcriptional changes [21,86-88], it is critical to examine the expression and turnover of protein products to complete our understanding of the cellular mechanisms behind coral stress response. Future studies should also consider examining specific genes of interest in concert with direct measurements of associated coral-specific phenotypes such as growth and lipid production $[89,90]$ in order to better understand the role of gene regulation in the acclimatization capacity of corals. Such validation studies are an essential step for discovering future biomarkers which can potentially be used as tools for coral restoration management. Nevertheless, our study illustrates that gene expression and photophysiological changes in corals are identifiable, thus paving the way for predictive monitoring of coral stress.

Supplementary Materials: The following are available online at http://www.mdpi.com/2076-2607/8/8/1227/s1, Figure S1: Calculated efficiencies (E) of designed primers for genes of interest-Camk4, Gas8, Hsp-16.1, KIF9; and internal control gene Actin, Data S1: Differential gene expression analysis using Poisson-based lognormal model to quantify changes in expression levels of all genes examined across experimental conditions.

Author Contributions: Conceptualization, R.C.P.-D., Y.L.G., D.H., L.M.C., P.A.T.; Experimentation, R.C.P.-D., and Y.L.G.; Analysis, R.C.P.-D., Y.L.G., and D.H. All authors contributed to manuscript revision. All authors have read and agreed to the published version of the manuscript.

Funding: This work was supported by the National Research Foundation, Prime Minister's Office, Singapore under its Marine Science Research and Development Program (Award Nos. MSRDP-P03 and MSRDP-P05).

Acknowledgments: We would like to acknowledge the St. John's Island National Marine Laboratory for providing the facility necessary for conducting the research. The Laboratory is a National Research Infrastructure under the National Research Foundation Singapore. Many thanks to Aden Ip, Yann Monteil, and Jain Sudhanshi Sanjeev for fieldwork and laboratory support. All fieldwork was conducted under the National Parks research permit NP/RP15-009a with permission from MPA.

Conflicts of Interest: The authors declare no conflict of interest. 


\section{References}

1. Hoegh-Guldberg, O.; Mumby, P.J.; Hooten, A.J.; Steneck, R.S.; Greenfield, P.; Gomez, E.; Harvell, C.D.; Sale, P.F.; Edwards, A.J.; Caldeira, K.; et al. Coral Reefs Under Rapid Climate Change and Ocean Acidification. Science 2007, 318, 1737-1742. [CrossRef]

2. Lough, J.; Anderson, K.D.; Hughes, T.P. Increasing thermal stress for tropical coral reefs: 1871-2017. Sci. Rep. 2018, 8, 6079. [CrossRef]

3. Hughes, T.P.; Barnes, M.; Bellwood, D.R.; Cinner, J.E.; Cumming, G.S.; Jackson, J.B.C.; Kleypas, J.; Van De Leemput, I.A.; Lough, J.; Morrison, T.H.; et al. Coral reefs in the Anthropocene. Nature 2017, 546, 82-90. [CrossRef]

4. Heron, S.F.; Maynard, J.A.; Van Hooidonk, R.; Eakin, C.M. Warming Trends and Bleaching Stress of the World's Coral Reefs 1985-2012. Sci. Rep. 2016, 6, 38402. [CrossRef]

5. Somero, G. The physiology of climate change: How potentials for acclimatization and genetic adaptation will determine 'winners' and 'losers'. J. Exp. Biol. 2010, 213, 912-920. [CrossRef]

6. Maor-Landaw, K.; Levy, O. Survey of Cnidarian Gene Expression Profiles in Response to Environmental Stressors: Summarizing 20 Years of Research, What Are We Heading for? Cnidaria Past Present Future 2016, 523-543. [CrossRef]

7. Sweet, M.; Brown, B. Coral Responses to Anthropogenic Stress in the Twenty-First Century: An Ecophysiological Perspective. Oceanogr. Mar. Biol. 2016, 54, 271-314. [CrossRef]

8. Venn, A.A.; Wilson, M.A.; Trapido-Rosenthal, H.G.; Keely, B.; Douglas, A.E. The impact of coral bleaching on the pigment profile of the symbiotic alga, Symbiodinium. Plant Cell Environ. 2006, 29, 2133-2142. [CrossRef] [PubMed]

9. Buddemeier, R.W.; Fautin, D.G. Coral Bleaching as an Adaptive Mechanism. Bioscience 1993, 43, $320-326$. [CrossRef]

10. Loya, Y.; Sakai, K.; Yamazato, K.; Nakano, Y.; Sambali, H.; Van Woesik, R. Coral bleaching: The winners and the losers. Ecol. Lett. 2001, 4, 122-131. [CrossRef]

11. Baker, A.C.; Glynn, P.W.; Riegl, B. Climate change and coral reef bleaching: An ecological assessment of long-term impacts, recovery trends and future outlook. Estuar. Coast. Shelf Sci. 2008, 80, 435-471. [CrossRef]

12. Ng, C.S.L.; Huang, D.; Toh, K.B.; Sam, S.Q.; Kikuzawa, Y.P.; Toh, T.C.; Taira, D.; Chan, Y.K.S.; Hung, L.Z.T.; Sim, W.T.; et al. Responses of urban reef corals during the 2016 mass bleaching event. Mar. Pollut. Bull. 2020, 154, 111111. [CrossRef] [PubMed]

13. Baena-González, E. Energy Signaling in the Regulation of Gene Expression during Stress. Mol. Plant 2010, 3, 300-313. [CrossRef] [PubMed]

14. Gates, R.D.; Edmunds, P.J. The Physiological Mechanisms of Acclimatization in Tropical Reef Corals. Am. Zool. 1999, 39, 30-43. [CrossRef]

15. Wund, M.A. Assessing the Impacts of Phenotypic Plasticity on Evolution. Integr. Comp. Biol. 2012, 52, 5-15. [CrossRef]

16. Stone, J.R. Phenotypic Evolution: A Reaction Norm Perspective; Carl, D., Ed.; Sinauer Associates Incorporated: Sunderland, MA, USA, 2000; Volume 75, pp. 55-56.

17. West-Eberhard, M.J. Phenotypic plasticity and the origins of diversity. Annu. Rev. Ecol. Syst. 1989, 20, 249-278. [CrossRef]

18. Wellband, K.; Heath, D.D. Plasticity in gene transcription explains the differential performance of two invasive fish species. Evol. Appl. 2017, 10, 563-576. [CrossRef]

19. Grenier, S.; Barre, P.; Litrico, I. Phenotypic Plasticity and Selection: Nonexclusive Mechanisms of Adaptation. Science 2016, 2016, 1-9. [CrossRef]

20. Barshis, D.J.; Ladner, J.T.; Oliver, T.A.; Seneca, F.; Traylor-Knowles, N.; Palumbi, S.R. Genomic basis for coral resilience to climate change. Proc. Natl. Acad. Sci. USA 2013, 110, 1387-1392. [CrossRef]

21. Mayfield, A.; Chen, Y.J.; Lu, C.Y.; Chen, C.S. The proteomic response of the reef coral Pocillopora acuta to experimentally elevated temperatures. PLoS ONE 2018, 13, e0192001. [CrossRef]

22. Anthony, K.R.N.; E Fabricius, K. Shifting roles of heterotrophy and autotrophy in coral energetics under varying turbidity. J. Exp. Mar. Biol. Ecol. 2000, 252, 221-253. [CrossRef] 
23. Lesser, M.P.; Weis, V.M.; Patterson, M.R.; Jokiel, P.L. Effects of morphology and water motion on carbon delivery and productivity in the reef coral, Pocillopora damicornis (Linnaeus): Diffusion barriers, inorganic carbon limitation, and biochemical plasticity. J. Exp. Mar. Biol. Ecol. 1994, 178, 153-179. [CrossRef]

24. Todd, P.A. Morphological plasticity in scleractinian corals. Biol. Rev. 2008, 83, 315-337. [CrossRef] [PubMed]

25. Ow, Y.X.; Todd, P.A. Light-induced morphological plasticity in the scleractinian coral Goniastrea pectinata and its functional significance. Coral Reefs 2010, 29, 797-808. [CrossRef]

26. Aubin-Horth, N.; Renn, S.C.P. Genomic reaction norms: Using integrative biology to understand molecular mechanisms of phenotypic plasticity. Mol. Ecol. 2009, 18, 3763-3780. [CrossRef]

27. Maury, L.L.; Marguerat, S.; Bähler, J. Tuning gene expression to changing environments: From rapid responses to evolutionary adaptation. Nat. Rev. Genet. 2008, 9, 583-593. [CrossRef]

28. Kenkel, C.D.; Aglyamova, G.; Alamaru, A.; Bhagooli, R.; Capper, R.; Cunning, R.; Devillers, A.; Haslun, J.A.; Hédouin, L.; Keshavmurthy, S.; et al. Development of Gene Expression Markers of Acute Heat-Light Stress in Reef-Building Corals of the Genus Porites. PLoS ONE 2011, 6, e26914. [CrossRef]

29. Seneca, F.; Forêt, S.; Ball, E.; Smith-Keune, C.; Miller, D.J.; Van Oppen, M. Patterns of Gene Expression in a Scleractinian Coral Undergoing Natural Bleaching. Mar. Biotechnol. 2009, 12, 594-604. [CrossRef]

30. Bay, L.K.; Ulstrup, K.E.; Nielsen, H.B.; Jarmer, H.; Goffard, N.; Willis, B.L.; Miller, D.J.; Van Oppen, M. Microarray analysis reveals transcriptional plasticity in the reef building coral Acropora millepora. Mol. Ecol. 2009, 18, 3062-3075. [CrossRef]

31. Császár, N.; Seneca, F.; Van Oppen, M. Variation in antioxidant gene expression in the scleractinian coral Acropora millepora under laboratory thermal stress. Mar. Ecol. Prog. Ser. 2009, 392, 93-102. [CrossRef]

32. Stearns, S.C. The Evolutionary Significance of Phenotypic Plasticity. Bioscience 1989, 39, 436-445. [CrossRef]

33. Drury, C.; Manzello, D.; Lirman, D. Genotype and local environment dynamically influence growth, disturbance response and survivorship in the threatened coral, Acropora cervicornis. PLOS ONE 2017, 12, e0174000. [CrossRef]

34. Kenkel, C.D.; Matz, M.V. Gene expression plasticity as a mechanism of coral adaptation to a variable environment. Nat. Ecol. Evol. 2016, 1, 14. [CrossRef] [PubMed]

35. Guest, J.R.; Baird, A.H.; Maynard, J.A.; Muttaqin, E.; Edwards, A.J.; Campbell, S.J.; Yewdall, K.; Affendi, Y.A.; Chou, L.M. Contrasting patterns of coral bleaching susceptibility in 2010 suggest an adaptive response to thermal stress. PLoS ONE 2012, 7. [CrossRef] [PubMed]

36. Epstein, H.E.; Torda, G.; van Oppen, M.J.H. Relative stability of the Pocillopora acuta microbiome throughout a thermal stress event. Coral Reefs 2019, 38, 373-386. [CrossRef]

37. Smith, H.; Epstein, H.; Torda, G. The molecular basis of differential morphology and bleaching thresholds in two morphs of the coral Pocillopora acuta. Sci. Rep. 2017, 7, 10066. [CrossRef]

38. Poquita-Du, R.C.; Huang, D.; Chou, L.M.; Todd, P.A. Mrinalini Short Term Exposure to Heat and Sediment Triggers Changes in Coral Gene Expression and Photo-Physiological Performance. Front. Mar. Sci. 2019, 6, 6. [CrossRef]

39. Schmidt-Roach, S.; Miller, K.J.; Lundgren, P.; Andreakis, N. With eyes wide open: A revision of species within and closely related to the Pocillopora damicornis species complex (Scleractinia: Pocilloporidae) using morphology and genetics. Zool. J. Linnean. Soc. 2014, 170, 1-33. [CrossRef]

40. Chou, L.M.; Toh, T.C.; Toh, K.B.; Ng, C.S.L.; Cabaitan, P.; Tun, K.; Goh, E.; Afiq-Rosli, L.; Taira, D.; Poquita-Du, R.C.; et al. Differential response of coral assemblages to thermal stress underscores the complexity in predicting bleaching susceptibility. PLOS ONE 2016, 11, e0159755. [CrossRef]

41. Toh, T.C.; Huang, D.; Tun, K.; Chou, L.M. Summary of coral bleaching from 2014 to 2017 in Singapore. In Status of Coral Reefs in East Asian Seas Region: 2018; Kimura, T., Tun, K., Chou, L.M., Eds.; Ministry of the Environment of Japan and Japan Wildlife Research Center: Tokyo, Japan, 2018; pp. 21-23.

42. Ralph, P.L.; Gademann, R.; Larkum, A.; Schreiber, U. In situ underwater measurements of photosynthetic activity of coral zooxanthellae and other reef-dwelling dinoflagellate endosymbionts. Mar. Ecol. Prog. Ser. 1999, 180, 139-147. [CrossRef]

43. Ben-Haim, Y.; Zicherman-Keren, M.; Rosenberg, E. Temperature-Regulated Bleaching and Lysis of the Coral Pocillopora damicornis by the Novel Pathogen Vibrio coralliilyticus. Appl. Environ. Microbiol. 2003, 69, 4236-4242. [CrossRef] [PubMed]

44. Jeffrey, S.; Humphrey, G. New spectrophotometric equations for determining chlorophylls a, b, c1 and c2 in higher plants, algae and natural phytoplankton. Biochem. Physiol. Pflanz. 1975, 167, 191-194. [CrossRef] 
45. Matz, M.V.; Wright, R.M.; Scott, J.G. No Control Genes Required: Bayesian Analysis of qRT-PCR Data. PLoS ONE 2013, 8, e71448. [CrossRef]

46. R Core Team. R: A Language and Environment for Statistical Computing; R Foundation of Statistical Computing: Vienna, Austria, 2018; Available online: http://www.R-project.org/ (accessed on 4 February 2018).

47. Morrison, T.; Hurley, J.; Garcia, J.; Yoder, K.; Katz, A.; Roberts, D.; Cho, J.; Kanigan, T.; Ilyin, S.E.; Horowitz, D.; et al. Nanoliter high throughput quantitative PCR. Nucleic Acids Res. 2006, 34, e123. [CrossRef] [PubMed]

48. Lalam, N. Statistical Inference for Quantitative Polymerase Chain Reaction Using a Hidden Markov Model: A Bayesian Approach. Stat. Appl. Genet. Mol. Biol. 2007, 6, 1-33. [CrossRef] [PubMed]

49. Sivaganesan, M.; Seifring, S.; Varma, M.; Haugland, R.A.; Shanks, O.C. A Bayesian method for calculating real-time quantitative PCR calibration curves using absolute plasmid DNA standards. BMC Bioinform. 2008, 9, 120. [CrossRef] [PubMed]

50. Follestad, T.; Jørstad, T.S.; Erlandsen, S.E.; Sandvik, A.K.; Bones, A.M.; Langaas, M. A Bayesian hierarchical model for quantitative real-time PCR data. Stat. Appl. Genet. Mol. Biol. 2010, 9, 3. [CrossRef]

51. Paradis, M.E.; Haine, D.; Gillespie, B.; Oliver, S.P.; Messier, S.; Comeau, J.; Scholl, D.T. Bayesian estimation of the diagnostic accuracy of a multiplex real-time PCR assay and bacteriological culture for 4 common bovine intramammary pathogens. J. Dairy Sci. 2012, 95, 6436-6448. [CrossRef]

52. Warner, M.E.; Fitt, W.K.; Schmidt, G.W. The effects of elevated temperature on the photosynthetic efficiency of zooxanthellae in hospite from four different species of reef coral: A novel approach. Plant Cell Environ. 1996, 19, 291-299. [CrossRef]

53. Hoegh-Guldberg, O. Climate change, coral bleaching and the future of the world's coral reefs. Mar. Freshw. Res. 1999, 50, 839. [CrossRef]

54. Cifuentes, A.L.C.; Lozano-Cortés, D.F.; Zapata, F.A. Effect of short-term subaerial exposure on the cauliflower coral, Pocillopora damicornis, during a simulated extreme low-tide event. Coral Reefs 2017, 36, 401-414. [CrossRef]

55. Wooldridge, S.A. Breakdown of the coral-algae symbiosis: Towards formalising a linkage between warm-water bleaching thresholds and the growth rate of the intracellular zooxanthellae. Biogeosciences 2013, 10, 1647-1658. [CrossRef]

56. Hennige, S.J.; Suggett, D.J.; Warner, M.E.; McDougall, K.E.; Smith, D.J. Photobiology of Symbiodinium revisited: Bio-physical and bio-optical signatures. Coral Reefs 2009, 28, 179-195. [CrossRef]

57. Roth, M.S. The engine of the reef: Photobiology of the coral-algal symbiosis. Front. Microbiol. 2014, 5, 422. [CrossRef] [PubMed]

58. Tanzil, J.T.I.; Ng, A.P.K.; Tey, Y.Q.; Tan, B.H.Y.; Yun, E.Y.; Huang, D.; Abigayle, N.P.K.; Qing, T.Y.; Beverly, T.H.Y.; Eric, Y.Y.; et al. A preliminary characterisation of Symbiodinium diversity in some common corals from Singapore. Cosmos 2016, 12, 15-27. [CrossRef]

59. Poquita-Du, R.C.; Huang, D.; Chou, L.M.; Todd, P.A. The contribution of stress-tolerant endosymbiotic dinoflagellate Durusdinium to Pocillopora acuta survival in a highly urbanized reef system. Coral Reefs 2020, 1-11. [CrossRef]

60. Guest, J.R.; Low, J.; Tun, K.; Wilson, B.; Ng, C.; Raingeard, D.; Ulstrup, K.E.; Tanzil, J.T.I.; Todd, P.A.; Toh, T.C.; et al. Coral community response to bleaching on a highly disturbed reef. Sci. Rep. 2016, 6, 20717. [CrossRef]

61. Lough, J.M.; Barnes, D.J. Several centuries of variation in skeletal extension, density and calcification in massive Porites colonies from the Great Barrier Reef: A proxy for seawater temperature and a background of variability against which to identify unnatural change. J. Exp. Mar. Biol. Ecol. 1997, 211, 29-67. [CrossRef]

62. Marshall, A.T.; Clode, P. Calcification rate and the effect of temperature in a zooxanthellate and an azooxanthellate scleractinian reef coral. Coral Reefs 2004, 23, 218-224. [CrossRef]

63. Kruzic, P.; Sr_sen, P.; Benkovic, L. The impact of seawater temperature on coral growth parameters of the colonial coral Cladocora caespitosa (Anthozoa, Scleractinia) in the eastern Adriatic Sea. Facies 2012, 58, 477-491. [CrossRef]

64. Tanzil, J.T.I.; Brown, B.E.; Dunne, R.P.; Lee, J.N.; Kaandorp, J.A.; Todd, P.T. Regional decline in growth rates of massive Porites corals in Southeast Asia. Glob. Chang. Biol. 2013, 19, 30113023. [CrossRef] [PubMed]

65. DeSalvo, M.K.; Voolstra, C.R.; Sunagawa, S.; Schwarz, J.A.; Stillman, J.H.; Coffroth, M.A.; Szmant, A.M.; Medina, M. Differential gene expression during thermal stress and bleaching in the Caribbean coral Montastraea faveolata. Mol. Ecol. 2008, 17, 3952-3971. [CrossRef] [PubMed] 
66. Cohen, A.L.; McConnaughey, T.A. Geochemical perspectives on coral mineralization. Rev. Miner. Geochem. 2003, 54, 151-187. [CrossRef]

67. Allemand, D.; Tambuttè, É.; Zoccola, D.; Tambuttè, S. Coral calcification, cells to reefs. In Coral Reefs: An Ecosystem in Transition; Dubinsky, Z., Stambler, N., Eds.; Springer: Berlin/Heidelberg, Germany, 2011; pp. 119-150.

68. Lough, J.M.; Barnes, D.J. Environmental controls on growth of the massive coral Porites. J. Exp. Mar. Biol. Ecol. 2000, 245, 225243. [CrossRef]

69. Lough, J.M.; Cooper, T.F. New insights from coral growth band studies in an era of rapid environmental change. Earth Sci. Rev. 2011, 108, 170184. [CrossRef]

70. Howe, S.A.; Marshall, A.T. Temperature effects on calcification rate and skeletal deposition in the temperate coral, Plesiastrea versipora (Lamarck). J. Exp. Mar. Biol. 2002, 275, 63-81. [CrossRef]

71. Cole, C.; Finch, A.A.; Hintz, C.; Hintz, K.; Allison, N. Effects of seawater pCO2 and temperature on calcification and productivity in the coral genus Porites spp.: An exploration of potential interaction mechanisms. Coral Reefs 2018, 37, 471-481. [CrossRef]

72. Cunning, R.; Bay, R.A.; Gillette, P.; Baker, A.C.; Traylor-Knowles, N. Comparative analysis of the Pocillopora damicornis genome highlights role of immune system in coral evolution. Sci. Rep. 2018, 8, 16134. [CrossRef]

73. Taira, D.; Toh, T.C.; Ng, C.S.L.; Loke, H.X.; Afiq-Rosli, L.; Cabaitan, P.C.; Toh, K.B.; Poquita-Du, R.C.; Chou, L.M.; Song, T. Relocating bleached Platygyra sinensis facilitates recovery from thermal stress during a minor bleaching event. Mar. Freshw. Behav. Physiol. 2017, 50, 375-385. [CrossRef]

74. Browne, N.; Precht, E.; Last, K.; Todd, P. Photo-physiological costs associated with acute sediment stress events in three near-shore turbid water corals. Mar. Ecol. Prog. Ser. 2014, 502, 129-143. [CrossRef]

75. Fabricius, K.E. Effects of irradiance, flow, and colony pigmentation on the temperature microenvironment around corals: Implications for coral bleaching? Limnol. Oceanogr. 2006, 51, 30-37. [CrossRef]

76. Hawley, S.A.; Pan, D.A.; Mustard, K.J.; Ross, L.; Bain, J.; Edelman, A.M.; Frenguelli, B.G.; Hardie, D.G. Calmodulin-dependent protein kinase kinase-beta is an alternative upstream kinase for AMP-activated protein kinase. Cell Metab. 2005, 2, 9-19. [CrossRef] [PubMed]

77. Rosic, N.; Kaniewska, P.; Chan, C.K.K.; Ling, E.Y.S.; Edwards, D.; Dove, S.G.; Hoegh-Guldberg, O. Early transcriptional changes in the reef-building coral Acropora aspera in response to thermal and nutrient stress. BMC Genom. 2014, 15, 1052. [CrossRef] [PubMed]

78. DeSalvo, M.; Sunagawa, S.; Voolstra, C.; Medina, M. Transcriptomic responses to heat stress and bleaching in the elkhorn coral Acropora palmata. Mar. Ecol. Prog. Ser. 2010, 402, 97-113. [CrossRef]

79. Richier, S.; Rodriguez-Lanetty, M.; Schnitzler, C.E.; Weis, V.M. Response of the symbiotic cnidarian Anthopleura elegantissima transcriptome to temperature and UV increase. Comp. Biochem. Physiol. D Genom. Proteom. 2008, 3, 283-289. [CrossRef]

80. Lesser, M.P. Oxidative stress causes coral bleaching during exposure to elevated temperature. Coral Reefs 1997, 16, 187-192. [CrossRef]

81. Hou, J.; Xu, T.; Su, D.; Wu, Y.; Cheng, L.; Wang, J.; Zhou, Z.; Wang, Y. RNA-Seq reveals extensive transcriptional response to heat stress in the stony coral Galaxea fascicularis. Front. Genet. 2018, 9, 37. [CrossRef]

82. Poquita-Du, R.C.; Ng, C.S.L.; Loo, J.; Afiq-Rosli, L.; Tay, Y.; Todd, P.A.; Chou, L.M.; Huang, D. New evidence shows that Pocillopora' damicornis-like' corals in Singapore are actually Pocillopora acuta (Scleractinia: Pocilloporidae). Biodivers. Data J. 2017, 5, e11407. [CrossRef]

83. Glynn, P.W.; Ault, J.S. A biogeographic analysis and review of the far eastern Pacific coral reef region. Coral Reefs 2000, 19, 1-23. [CrossRef]

84. Paz-Garcia, D.A.; Hellberg, M.E.; de-Leon, F.J.G.; Balart, E.F. Switch between morphospecies of Pocillopora corals. Am. Nat. 2015, 186, 434-440. [CrossRef]

85. Johnston, E.C.; Forsman, Z.H.; Flot, J.F.; Schmidt-Roach, S.; Pinzon, J.H.; Knapp, I.S.S.; Toonen, R.J. A genomic glance through the fog of plasticity and diversification in Pocillopora. Sci. Rep. 2017, 7, 5991. [CrossRef] [PubMed]

86. Cziesielski, M.J.; Liew, Y.J.; Cui, G.; Schmidt-Roach, S.; Campana, S.; Marondedze, C.; Aranda, M. Multi-omics analysis of thermal stress response in a zooxanthellate cnidarian reveals the importance of associating with thermotolerant symbionts. Proc. R. Soc. B 2018, 285, 20172654. [CrossRef] [PubMed] 
87. Mayfield, A.B.; Wang, Y.B.; Chen, C.S.; Chen, S.H.; Lin, C.Y. Dual-compartmental transcriptomic + proteomic analysis of a marine endosymbiosis exposed to environmental change. Mol. Ecol. 2016, 25, 5944-5958. [CrossRef] [PubMed]

88. Ramírez-Carreto, S.; Vera-Estrella, R.; Portillo-Bobadilla, T.; Licea-Navarro, A.; Bernaldez-Sarabia, J.; Rudiño-Piñera, E.; Verleyen, J.J.; Rodríguez, E.; Rodríguez-Almazán, C. Transcriptomic and proteomic analysis of the tentacles and mucus of Anthopleura dowii Verrill, 1869. Mar. Drugs. 2019, 17, 436. [CrossRef]

89. Baumann, J.; Grottoli, A.G.; Hughes, A.D.; Matsui, Y. Photoautotrophic and heterotrophic carbon in bleached and non-bleached coral lipid acquisition and storage. J. Exp. Mar. Biol. Ecol. 2014, 461, 469-478. [CrossRef]

90. Yamashiro, H.; Oku, H.; Onaga, K. Effect of bleaching on lipid content and composition of Okinawan corals. Fish. Sci. 2005, 71, 448-453. [CrossRef]

(C) 2020 by the authors. Licensee MDPI, Basel, Switzerland. This article is an open access article distributed under the terms and conditions of the Creative Commons Attribution (CC BY) license (http://creativecommons.org/licenses/by/4.0/). 